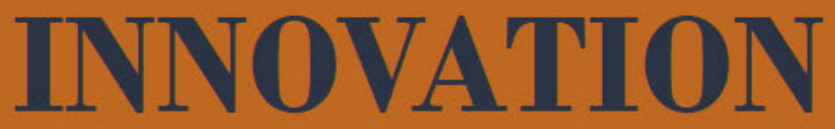

AND TRANSITION

IN LAW Experiences

and Theoretical

Settings

Edited by

Massimo Meccarelli

Cristiano Paixão

Claudia Roesler 

Innovation and Transition in Law:

Experiences and Theoretical Settings 
The Figuerola Institute

Programme: Legal History

The Programme "Legal History" of the Figuerola Institute of Social Science History -a part of the Carlos III University of Madrid- is devoted to improve the overall knowledge on the history of law from different points of view -academically, culturally, socially, and institutionally- covering both ancient and modern eras. A number of experts from several countries have participated in the Programme, bringing in their specialized knowledge and dedication to the subject of their expertise.

To give a better visibility of its activities, the Programme has published in its Book Series a number of monographs on the different aspects of its academic discipline.

Publisher:

Carlos III University of Madrid

Book Series:

Legal History

Editorial Committee:

Manuel Ángel Bermejo Castrillo, Universidad Carlos III de Madrid

Catherine Fillon, Université Jean Moulin Lyon 3

Manuel Martínez Neira, Universidad Carlos III de Madrid

Carlos Petit, Universidad de Huelva

Cristina Vano, Università degli studi di Napoli Federico II

More information at www.uc3m.es/legal_history 
Innovation and Transition in Law:

Experiences and Theoretical Settings

\author{
Edited by \\ Massimo Meccarelli \\ Cristiano Paixão \\ Claudia Roesler
}

DYKINSON

2020 
Historia del derecho, 87

ISSN: 2255-5137

(C) 2020 Autores

\section{Editorial Dykinson}

c/ Meléndez Valdés, 61 - 28015 Madrid

Tlf. (+34) 915442846

E-mail: info@dykinson.com

http://www.dykinson.com

Preimpresión: TALLERONCE

ISBN: 978 84-1377-163-2

Depósito legal: M-29503-2020

Versión electrónica disponible en e-Archivo

http://hdl.handle.net/10016/31394

\section{(c) (1) (8)}

Licencia Creative Commons Atribución-NoComercial-SinDerivadas 3.o España 


\section{INDEX}

Massimo Meccarelli, Cristiano Paixão, Claudia Roesler, Innovation and transition in law: some introductory remarks on the heuristic value of

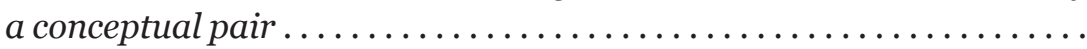

\section{Setting Concepts}

Massimo Meccarelli, Time of innovation and time of transition shaping the legal dimension: a methodological approach from legal history ....

Maria Pia Guerra, What is a legal transition? Thoughts on legal change amidst a political transition (Brazil, 1980-2020) ................

Flavia Stara, New philosophical paradigms and demand for law: space for innovation. Reflections on the time of transition as a practical structure .........................................

Douglas Antônio Rocha Pinheiro, Melancholy as a permanent transition in law and democracy ...............................

Cristiano Paixão, Uses of silence in political and legal transitions: a methodological approach to constitutional history ................

Considering Semantics

Claudia Roesler, Legal concepts from the standpoint of innovation and preservation of meaning: a rhetorical perspective ................

Francesco Gambino, Latent innovations in a legal system and civil law categories .......................................

Antonella Meniconi, The words of Justice and the long italian transi-

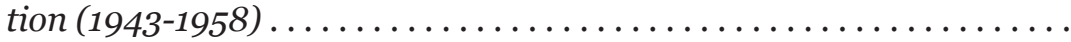

Isaac Costa Reis, Rhetoric, technological innovation and legal audiences: the case of Brazilian Supreme Court .................. 
Dealing with Experiences

Raphael Peixoto de Paula Marques, Constituent power and constitutional change in Brazil's transition to democracy (1945-1946) ........

Claudia Paiva Carvalho, Transition to democracy and the Brazilian presidential system post-1946: the relationship between institutional design and political instability . . . . . . . . . . . . . . . . . . . . . .

Elisabetta Fusar Poli, The physical body through the juridical lens: an issue of law of innovation and of innovation in law (XIX-XX cent.)....

Francesca Martello, From telegraph to telephone: an exemplary transitional space in the legal discipline of technical innovations (18771903) .........................................

Alessio Bartolacelli, In the middle of nowhere. The never-ending transition of Italian private companies (società a responsabilità limitata

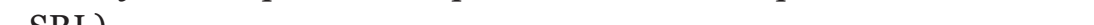
- SRL) ..............................................

Giovanni Di Cosimo, The evolution of the form of government in Italy .... 305

List of Contributors .............................. 349 


\title{
Latent innovations in a legal system and civil law categories
}

\author{
Francesco Gambino
}

1. Radical and latent innovations in a legal system; 2. The legal language in conceptual, cultural and juridical innovations. Language as a thought-forming organ; 3. Confining the semantic space of reference; 4. Principles, general provisions, new forms of reasoning; 5 . Structure of a legal system and the balance of powers; 6 . Authentic innovations and individual cognitive horizons

\section{Radical and latent innovations in a legal system}

Among the themes arising from a reflection on innovation and transition in a legal system, one in particular stands out: the most problematic, which could be defined as the theme of the "passages" constituting what is "novel" in the legal world. The law assumes many faces; ${ }^{1}$ as many faces as the legal phenomenon can assume according to different conceptions. Therefore, in agreeing on giving transition an "ascriptive" function, as a way in which innovation can manifest itself, ${ }^{2}$ it is nonetheless essential to mark a general distinction. For the purposes of this paper, in a legal system (or, if you wish, in a legal order), ${ }^{3}$ it is necessary to differentiate patent and radical innovations from the surreptitious or latent innovations.

The first - the radical innovations - boil down to the historical facts that

1 Simply consider the debate that took place in the early decades of the 190os on the confusion between the different tasks assigned to legal science and to legal practitioners (in particular from the perspective of wilfully exercising a function) that produced the result whereby the former became "the featherbed of practice". Merkl (1987) 122.

2 See in this volume the chapter by Massimo Meccarelli.

3 In this preliminary reconstruction, let us leave aside the question of what can be defined as ideal and what is real and effective in an order, namely the difference between a set of norms and the powers that produce and enforce them, turning the law into "organization, structure, the very stand taken by society". Romano (1962) 27. The lesson delivered by Santi Romano, who reported the crisis of the hierarchy of sources and refused legal positivism. Grossi $(2006$; 2011) 49. In this context, we can read the essays by Gunther Teubner (2005). More recently, a number of contributions on Teubner's thoughts by scholars in civil law, sociology, and in the philosophy of law have been published. See Febbrajo/ Gambino (eds.) (2013). 
gave rise to new institutions and new regulatory frameworks that are operational, binding and effective. The others - the latent innovations which also project new contents within given semantic formations $-^{4}$ arise from those who take on the task of interpreting a given system (legal practitioners, legal theory, caselaw) and from the way they narrate the law, with a view to meeting the expectations and the prospected expectations of a community. Here, the difficulty - as will be outlined below - lies in understanding and recognising the authenticity of innovation as it arises from the meaning, dimension and stability of the phenomenon that breaks with the past.

To give an idea of radical innovation - and its incidence upon language and culture - we can recall a few historical events.

By way of example, let us think of the period in the mid- $19^{\text {th }}$ century in which Italy was getting ready to take the road of political, legislative, economic and administrative unification in the name of continuity with the experiences of the past. ${ }^{5}$ This was the period in which theoretical elaborations and legal categories suffered the impact of history. The cultural framework enshrining the 1865 Civil Code, which was moulded on the Napoleonic Code of 1804 , features the economic and social needs of bourgeois ideology: ${ }^{6}$ the individual, subjective rights, the contract, succession mortis causa. The exegetic method, exercised in compliance with the order laid down by the civil code, results from the closely-knit intertwining between legal theorizing and law-making activities, "gathered together in the unity of the liberal State".7

To make another example, reference can be made to the changes brought about to the political and legal order through the introduction of a Constitution. ${ }^{8}$ In Italy, the Republican Constitution of 1948 , by placing itself at the apex of the legal order, downgrades the Provisions on the law in general to a

4 If we trace the reasoning of Koselleck (2010) 51-66, we can clarify the fact that "innovating, in this sense, means finding a way of projecting new contents within semantic formations that, whether created for the sake of innovation or not, can be adequately mirrored in already shared understandings", as explained in the chapter by Claudia Roesler in this volume.

5 The widespread concern of preserving continuity with the past especially in administration matters is highlighted in the essay by Cassese (2011) $305 \mathrm{ff}$., whose title quotes the words that Camillo Benso di Cavour wrote in a letter of 19-10-1860 (306, nt. 4).

6 Irti (1990) 4.

7 Irti (1990) 5 .

8 The relationship between the law and the Constitution is cited as an example of transition and innovation in the contribution by Meccarelli in this volume. 
lower-ranking legal source. The soundness of the normative method spread among scholars and practitioners of law up to that moment was fatally shaken. The coming into force of the Constitution marked a new philosophical approach - the philosophy of values $-{ }^{9}$ which opened up to the prevalent interests enshrined in the Constitution. The "value-based" points of view supporting the argumentations dictated by socially recognized values ${ }^{10}$ meet the axiological need to control the jurist's interpretative and constructive efforts.

We can ultimately backtrack even further in history and recall the abolition of the nexum with which the debtor was enslaved to the creditor, who was "entitled to keep the nexus, i.e. the obligatus, in chains, beat him with a cane, and oblige him to work for him". ${ }^{11}$ The "terrible effectiveness" of the nexum, which was the cause of unruly fights between patrician creditors and plebeian debtors, persisted until the passing of the lex Poetelia in $326 \mathrm{BC}$, which abolished the institution. This is the point in history in which the modern sense of obligation arose: ${ }^{12}$ the transition from the personal and coercive subjugation of the debtor to a relationship of a pecuniary nature. The "obligation" loses its original connotation and is normalized, if I may use this term.

The word, stripped of its etymological halo and acquiring a new evolutionary phase of meaning, frees itself of the material person of the debtor.

It is the very first trace of the full objectification process that, with the full development of a legal culture, will ultimately end up by anchoring the liability arising from the obligation to the debtor's assets.

2. The legal language in conceptual, cultural and juridical innovations. Language as a thought-forming organ

In what we here define as innovation, both patent and latent, the common ground is laid down by the language. ${ }^{13}$ It is within the linguistic structure that innovations - forms of thought capable of stabilizing and prevailing in solving legal and social problems - are created and recognized. ${ }^{14}$ The stabilization process - in the presence of an authentic conceptual, cultural or legal inno-

9 To explore this approach, which in Italy will follow other paths of reasoning, see the reconstruction made by Irti (2011) 98-100.

10 Mengoni (1996) 85 .

11 Bonfante (1946) 372.

12 Bonfante (1946) 304, 372.

13 See Roesler's chapter in this volume.

14 See Roesler's chapter in this volume. 
vation - is made possible by the interaction of a given language with our way of conceiving and perceiving the world. Because language, as we can read in the writings of Humboldt, is "the thought-forming organ" and must exist in close connection with the laws of grammar and the laws of thought. ${ }^{15}$ In my opinion, by following this line of thought - developed in the studies of Franz Boas and Roman Jakobson $-{ }^{16}$ we can affirm that the legal language does not function differently from other languages and can also say that it - exactly like any other language - is not so much characterized by what it enables one to think as much as by what it "habitually obliges given types of information to think". ${ }^{17}$ In Guy Deutscher's reconstruction, when a language "obliges its speakers to pay attention to certain aspects of the world every time they open their mouths or prick up their ears, at the end these linguistic habits can translate into mental habits that produce consequences on memory, perception, associations or even practical skills." ${ }^{18}$ In the light of these findings, we could say that the stability of an innovation in the world of law is marked by the conversion of a linguistic option into a linguistic habit. It is a sense of constraint that, in the totality of meanings in which we live, leads to increasing or decreasing our possible options.

The meaning of certain things on our lives and goals manifest themselves in a new way. We could even speak of a new form of usability ${ }^{19}$ of legal things. Thus, for example, with the abolition of the nexum, the concept of obligation begins to lose its material connotation and enters a new domain of constitution and validity, ${ }^{20}$ generates new rules for use, and launches new theoretical processes. With the abolition of the institution of the nexum or, in more recent times, of the arrest for debt (provided for in the civil code of 1865) or of

15 Wilhelm von Humboldt's insight on the theme of the influence of language on the mind is cited in the writings of Deutscher (2016) 151-158.

16 See the Boas-Jakobson principle as recalled in the words of Deutscher (2016) 173179.

17 Deutscher (2016) 175.

18 Deutscher (2016) 175 .

19 Gianni Vattimo (2000) 23, dwells on the German term Zuhandenheit, used by Martin Heidegger (1971) 88-92 in the context of the "worldhood" of the world, in which the usability of the meaning of things in connection to our lives "is their way of giving themselves a more original meaning, the way in which they first come up in our experience".

20 See the reference made to the studies conducted by Georges Canguilhem on "transformations" and on the "shifting" of concepts, Foucault (1999) 7. 
the "stone of shame" used in a little town in Sicily up to the $1920 s,{ }^{21}$ debt is necessarily destined to assume a less afflictive and menacing meaning, psychologically remote from being synonymous to social guilt and shame.

Both in radical and latent innovations, words, concepts, and their variations in meaning, penetrate the legal system, modifying its features. ${ }^{22}$ While in radical innovations, the construction of a new symbolic space is achieved in the sign of an evident break with the old world, ${ }^{23}$ in latent innovations, it is the hidden measure of the break with the past that indicates the degree of authenticity of the innovation. In my opinion, in the latter there is the decisive need - pointed out by Koselleck - to effectively prove their newness and what results to only be a new way of appearing of unvaried structures. ${ }^{24}$ Here, the sense of constraint underlying a new mental habit arises from an unspecified point of intersection between a certain way of narrating and of interpreting the law through the expectations of communities in a given historical period.

\section{Confining the semantic space of reference}

In the perspective outlined by scholars of the language, reference should now be made to the evident tendency in civil law to replace solid and age-old categories of the past with new paradigms and conceptual orders. In an approach that also involves other disciplines, it becomes essential to confine the semantic space of reference. This space - against which the system's latent innovations are measured - is occupied by judicial decisions in which the selection of the legal judgment criteria, by reflecting on the ways in which right or wrong is awarded in the trial, carries the weight of an underlying cultural responsibility. We are here referring to the context of wilful acts that, by deciding the outcome of a controversy, require control techniques over the argumentations used to justify the soundness of the decision. The matter of the fact is that civil law, not always necessarily bound to the facts, presents the possibility of inventive elements in a situation in which the audience $^{25}$ is

21 See in this respect the lectio brevis titled Dalla «pietra del vituperio» al «bail-in» delivered by Portale (2016).

22 Here, we see the return of the idea of the "ascriptive value" of the transition as an innovation: "a temporal condition capable of attributing specific regimes and contents to the law" as is explained in the chapter by Meccarelli in this volume.

23 See Foucault (1999) 6-7.

24 See on this point the chapter by Claudia Roesler in this volume.

25 In the development of the new rhetoric propounded by Chaïm Perelman (1966) 21, 
commonly made up by the parties to the trial, the higher-ranking judge and the scientific community.

\section{Principles, general provisions, new forms of reasoning}

It is now twenty years that in Italy the idea of a "factual" law - already present in our studies and in our Courts of justice - has been growing. The third party that decides on the case is no longer "the mouth of the law". He or she is reluctant to keep to the letter of the law and, in awarding right or wrong, does not hesitate to base his/her decision on constitutional principles, general principles, extra-judicial judgment criteria, the new lex mercatoria, the law of the European Union and also on foreign legal orders. A rigidly hierarchical system is being challenged by a flexible and heterarchical system, more in line with the cultural environment of common law systems. General principles and general provisions operate as "flexible things" that, by penetrating the judges' decisions, threaten the primacy of the law, making it inconstant and uncertain. It is the consequence of an overall conception of the law that, reflecting the erosion of the juridical nature of the State, sees the law as a phenomenon in perennial movement, in which the balance in the legislator-judge relationship changes, the general provisions become the conceptual crux from which a new law evolves, and general principles penetrate the norms and overturn their interpretation. In certain approaches, the design is to adjust the law to social, economic and natural facts and to adapt legal forms to the specificity and urgency of the case at hand. This can be done in a variety of ways. From the perspective of the interpretation activities carried out within the framework of Italian legal theory and caselaw, notice should here be taken of two new phenomena: $a$ ) general principles and provisions applied against the norms; $b$ ) building a legal paradigm on principles. In the first case, general provisions and principles prevail over legislative regulation. The second case raises the problem of building a legal paradigm in the absence of a norm.

The following pages will focus attention on the future application of the general good faith provision on the basis of the definitions given by Italian caselaw. The decision of a district court states that Art. 1375 of the Civil Code, which lays down that "the contract must be executed in good faith", must be

the audience is defined as "the group of people that the speaker wants to influence through his argumentations“. 
understood as referring to the principle of objective good faith which, as it regulates every phase of the contract - from its formation and interpretation to its execution - configures a general provision grounded on the duty of solidarity laid down in Art. 2 of the Constitution and functions as a criterion of reciprocity, regardless of the existence of contractual or legal obligations to this effect. ${ }^{26}$

Here, the reasoning can unfold in simplified and intuitive terms, more open to intercept the application of other disciplines.

To act in good faith in executing an agreement means to honour a general duty - which applies to all the parties to any contract - to safeguard (or, if you like, to protect) third party interests to the extent that this does not entail a significant sacrifice of one's own interests. The general good faith provision is grounded on the idea that contractual agreements are incapable of expressing everything. They are necessarily incomplete programmes. The approach taken by some legal practitioners in tackling economically relevant contracts is to clarify and specify a multitude of required behaviours (stating the definition of the terms used in the contract in the recitals to analytically indicate the content of contractual clauses). The most common approach is to leave it up to the interpreter to fill in, so to speak, some of the effects of the contracts by applying the general provision. This is what makes the principle of good faith in contracts contentious. Under the legal relationship of a contract and lacking the indication of the importance of a given behaviour therein, the parties are given ample scope of discretion. If the parties reach an agreement on a controversial behaviour in the execution of a contract, then there is no issue. If, on the contrary, they come into conflict, it will be up to the judge to decide by denouncing, so to speak, the legal existence of the behaviour that, deemed relevant from the point of view of the good faith principle, will oblige the wrongdoer to reimburse the damage.

Let us imagine a first situation. Is the contracting party obliged to tolerate that - for unexpected reasons, extraneous to the will of the parties - the goods purchased are delivered to a different address not far from the one indicated in the contract? The law tends towards proportionality and therefore the answer here is positive. In this case, by virtue of the good faith principle, the creditor is obliged to tolerate a defective performance of contract. Already the words "tolerate" and "defective" performance (not "non-performance")

26 Court of Appeal of Rome, Section II Ruling N.5300 of 16 December 2010, here in summary, in the databank of De Jure. 
well express the idea underlying the contractual good faith principle of protecting third party interests to the extent that this does not entail a significant sacrifice of one's own interests.

Different is the case, pursuant to the general good faith provision, of the recognised possibility of extinguishing one's pecuniary obligations with a cashier's check ${ }^{27}$ (which, according to an approach taken in caselaw, opens the door to the use of alternative means of payment other than cash). This is an innovative solution that overlaps the literal wording of Art. 1277, Para.1, of the Italian Civil Code which reads as follows: "pecuniary debts are extinguished with the legal tender in the State at the time of the payment and for its nominal value". From the perspective of interpretation, there is the problem of understanding if contractual good faith - as the specification of the constitutional principle of social solidarity - is capable of converting the expression "legal tender" (meaning money in cash) into a more generic expression (for example: "monetary value") in order to attribute to the debtor the faculty of paying with a means other than in cash. Relying on a constitutionally-oriented interpretation of Art. 1277 of the Italian Civil Code, the Court of Cassation, in joint session, imposed on the creditor - who is obliged to behave in good faith - the obligation to accept means of contractual performance that are alternative to the delivery - at home - of money in cash. ${ }^{28}$ This interpretation of Art. 1277 of the Civil Code - according to the Court of Cassation - "goes beyond the literal wording and, by grasping its authentic sense, adapts it to the changed reality". ${ }^{29}$

This is an approach that - although sensitive to the new and increasingly sophisticated money circulating instruments - raises the problem of a new form of reasoning or, if you prefer, of a new legal argumentation technique. The term of reference in the selection of the criteria for the judgement - criteria ultimately aimed at awarding right or wrong in a trial - is no longer the "sense made patent by the specific meaning of the words" used by the legislator, meaning thereby the literal meaning to which the interpreter is bound pursuant to Art. 12 of the Provisions on the law in general, ${ }^{30}$ but rather the

27 See - on the issue of cashless payments - the ruling of the Court of Cassation, Joint Session, N. 26617, 18 December 2007, in Corr. giur., 2008, p. 500 ff., with a note by Di Majo.

28 Court of Cassation, Joint Session, Ruling N. 26617, of 18 December 2007, op. cit.

29 Court of Cassation, Joint Session, Ruling N. 26617, of 18 December 2007, op. cit.

30 In the case at hand, the univocal meaning of the words "legal tender" contained in Art. 1277 of the Civil Code. 
fundamental duty of social solidarity enshrined in Art. 2 of the Constitution, which is useful to strengthen the argument of contractual good faith in the case at hand.

Let us now turn our attention to legal disputes over the abusive nature of exercising the faculty of withdrawing from a dealer agreement without cause. ${ }^{31}$ Can the licensor (in this case, automobile manufacturer Renault), holding an entitlement attributed to it by a clause - considered to be valid withdraw from the agreement (in the case at hand, with notice) without being obliged to compensate the damage caused to the dealers ${ }^{32}$ thus excluded from the contractual relationship?

According to the Court of Cassation, also in this case, good faith, fair play and the "fundamental duty of social solidarity" (Art. 2 of the Constitution) are the arguments that disclose the judicial control over the performance behaviour of the parties (in this case, the abusive nature of the licensor's concrete exercise of the right of withdrawal). ${ }^{33}$

As the Italian legal order lacks a provision on the abuse of a right, Courts are recognised the power to control the aims and ways also of a withdrawal from contract that was agreed to be free and unconditioned. In the ruling cited, the Court of Cassation relies on the general good faith provision in judging the reasons of the withdrawal, to establish if the formal legal framework was used for an end other than the reason for which it was developed and if the exercise of a right was actually abusive.

This conclusion, which raises some perplexity, waters down and downgrades the argumentative value of some civil law categories, age-old conceptual orders, and well-grounded interpretative approaches to legal problems (also present in the decision of the Court of Appeal of Rome quashed by the Court of Cassation). For the trial judge, the reasons of the automobile manufacturer's withdrawal are unquestionable or, if you prefer, unpierceable because upheld by the concept of validity, the notion of potestative right, and the principle of private autonomy. ${ }^{34}$ To declare a clause (the withdrawal

31 Court of Cassation ruling No. 20106 of 18 September 2009, in Giust. civ., 2009, I, p. 2671.

32 Note should be taken of the investments made by dealers and of other economic losses.

33 See on this point Court of Cassation ruling No. 20106 of 18 September 2009, in Giust. civ., 2009, I, p. 2671.

34 In this sense, the Court of Appeal of Rome (No. 136/2005, Sect. XI, of 28-9-200413-1-2005, in the ruling quashed by the Court of Cassation) laid down that "if autonomy 
clause) valid means evaluating it to be in compliance with the higher-ranking norms contained in the Civil Code, marking it as belonging to the legal system which, through its rules, approves the content of the clause. In other words, the act of withdrawing in conformity with a valid clause, does not fall under the protection of the good faith provision. ${ }^{35}$ In line with a traditional school of thought, University courses teach that a potestative right (in the case at hand, the right of withdrawal) is the power to produce a change in another person's legal sphere. It is not a right of claim which, in order to be fulfilled, needs the cooperation of the debtor, but a potestative right. Exercising this right puts the other party is in a position of subjection: he/she cannot avoid being subjected to the effects of the changes in his/her legal sphere. Lastly, reference is made to the private autonomy principle which, in a liberal order, also arises from the power to freely determine the content of the contract (Art. 1322, Para. 1 of the Civil Code).

These are the arguments relied on by the Court of Appeal of Rome to form its legal judgment on the concrete exercise of withdrawal without a cause. However, as has been pointed out, the reasoning developed by the Court of Cassation takes a different direction. The performance behaviour - in exercising the right of withdrawal - is no longer narrated according to the conceptual order with which jurists were accustomed to govern legal phenomena (the category of validity, the notion of potestative right, the principle of autonomy) but is placed in a new perspective in which the terms of reference change in formulating a judgment and awarding right or wrong (general good faith provision, duty of social solidarity, the specific case).

\section{Structure of a legal system and the balance of powers}

In the light of this approach we can now draw some conclusions. The scope of inquiry into the innovations in a legal system bear the effects of the historical relevance of particular determinations (a constitution, legal institutions, the interpretation of a law, the legal category of a people at a given point in time). It does not - or at least not yet - involve the radical question in the phi-

recognised the possibility of withdrawing from the contract, there is no need to control the cause of the exercise of power".

35 Relatively to the problem of the extent of the application of general good faith provisions, reference should be made to my book. See Gambino (2015) 207-239. 
losophy of law: quid ius? ${ }^{36}$ It does not intend to include what remains beyond the space-time conditions of particular determinations. ${ }^{37}$ It does not - or at least not yet - question why law exists in Man; nor does it single out, establish or confine conceptual autonomy within the "juridical" activity proper. The area of legal innovations or transitions is a field of research that delves into the knowledge of what belongs to the law (quid sit iuris) in a given place and time.

In this perspective and in illustrating the sense of latent innovations in a legal system, focus has been placed on the new ways of reasoning in certain judicial decisions in order to justify a well-grounded solution. It will always be possible to uphold the argumentative prevalence now of the law, now of a constitutional principle, now of a traditional category and now of the specific case to be decided. These oscillations often conceal single cultural stands, ideological principles, comprehensive conceptions of the law. The underlying problem is to establish the place of certainty that harbours the possibility of legally measuring our behaviours; which means establishing the rules of the game so that individuals may know what to do. ${ }^{38}$ This symbolic space as revealed with respect to the issues put forth above - is at times disputed by the univocal words used by the legislator, at times by the programming force of the words with which private individuals commit to future actions and express their autonomy from the legal order, and at times by the judicial precedent ${ }^{39}$ which, as we have seen, is increasingly sensitive to historic occurrences, concrete cases and performance behaviours.

36 In raising this fundamental question (quid ius?), Immanuel Kant (2009), in his famous introduction to legal theory, makes it a point from to distinguishing it from the question on "knowing and stating what falls under the law (quid sit iuris)", which means "what the laws in a given place and given time say or have said", warning people to abandon "a merely empirical theory that is void of rational principles," and "searching for the sources of such judgments, in order to lay a real foundation for actual positive legislation".

37 This would only have the purpose of establishing why all that is commonly qualified as the law exists. Cotta (1985) 13-14.

38 In respect of the different conceptions of the law, it will always be possible to question the criteria of legality but not the indeclinable need to be able to predict, control, and foretell the legal consequences of our actions. The law, by its very nature, considers and plans the future in the prospect of giving a new direction to the actions of Man.

39 Already in the '90s, Luigi Mengoni (1992; 2011) 253, perceived the need, in Italian law, of the urgency of a theory of judicial precedents compatible with the legal orders of civil law. 
In a democratic system based on communicating vessels, underlying these different ways of reasoning thrives the balance of power and conflict between the legislative and judicial powers, between the "word" of the legislator, who always reasons on general and future things, and the "word" of the judge, who represents the place in which the law, by deciding on particular issues, is made ex post..$^{40}$ If, on the one hand, the idea of an ex post law - increasingly present in modern judicial systems - of a judicial phenomenon disconnected from the political power, and of creative and incalculable judicial decisions, in some cases becomes a defence, ${ }^{41}$ on the other hand, it raises the problem of the limits of compatibility between the expanded scope of freedom of a power and the survival of a given social system that we confide will continue functioning.

\section{Authentic innovations and individual cognitive horizons}

Once the paradigms now making their way into the Courts of justice become permanent, repetitive, uniform structures, they will end up involving the structural elements of the legal system. It will be the longevity of the effectiveness of persuasion of new language formations and conceptual orders or, if you prefer, of the continuance of the break with the past over time that will qualify the innovation as authentic. The problem remains of matching a certain way of interpreting the law with the expectations of a society. We could say that an unspecified number of individual narrations ${ }^{42}$ of a historical, cultural, or legal memory, made at a given point in time, matches the

40 Cassese (2009) 34, wrote: "today the law is, to a large extent, fruit of the ex post research into sets of separate rules deriving from the multiplication of norm-producing centres".

41 Nowadays, note should be taken of the ambiguity of legislative language, the wording of texts that does not correspond to the intended political action, and the introduction of obscure, inaccessible norms difficult to understand.

42 In commenting European humankind, religious incredulity and the attitude to give up philosophy up to scientificity, Husserl (2014) 41-42, wrote: "Man is only capable of developing an idea from his own position, from his own cognitive and sentimental horizons, thus forming paths in which to believe, as they constitute his vision of the world, provide him with personal evidence of an idea and of a norm of the action guided by what is thought and believed to be absolute. This attitude exists in human groups that share the same original tendencies which subsequently concretise in a common way of feeling and proceeding". 
sense expected by a community. However, the degree of intensity of those expectations is impossible to know and to prove. The correspondence between individual cognitive horizons - where ideas develop and psychological drives and feelings thrive ${ }^{43}$ and where judgments are formed and facts and laws are interpreted - and widespread consensus within a society, even if supported by quantitative indexes and statistical data, can only be inferred. After all, the process by which the unfolding of certain things over time is represented or narrated is not typical of science but of artistic creation. ${ }^{44}$

\section{References}

Bonfante, Pietro (1946), Istituzioni di diritto romano (1896), 10th edition, Torino, G. Giappichelli (reprinted in Milan, Giuffrè, 1987)

Cassese, Sabino (2009), Eclissi o rinascita del diritto?, in: Rossi, Pietro (ed.), Fine del diritto?, Bologna, Il Mulino

Cassese, Sabino (2011), "Fare l'Italia per costituirla poi”: Le continuità dello Stato, in: Riv. trim. dir. pubbl.

Cotta, Sergio (1985), Il diritto nell'esistenza: Linee di ontofenomenologia giuridica, Milano, Giuffrè

Croce, Benedetto (2017), La storia ridotta sotto il concetto generale dell'arte (1893), edited by G. Calasso, Milano, Adelphi

Deutscher, Guy (2016), La lingua colora il mondo: Come le parole deformano la realtà, Italian translation by E. Griseri, Torino, Bollati Boringhieri

Febbrajo, Alberto, Francesco Gambino (eds.) (2013), Il diritto frammentato, Milano, Giuffrè

Foucault, Michel (1999), L'archeologia del sapere: Una metodologia per la storia della cultura (1969), Italian translation by G. Bogliolo, Milano, Rizzoli

Freud, Sigmund (1976), Considerazioni attuali sulla guerra e la morte (1915), in Opere (1915-1917), Introduzione alla psicoanalisi e altri scritti, with the foreword by C. L. Musatti, Torino, Bollati Boringhieri

Gambino, Francesco (2015), Le obbligazioni, vol. 1, Il rapporto obbligatorio, in: Sacco, Rodolfo, Trattato di diritto civile, Milano, UTET

43 The psychoanalytic experience recalled in the chapter by Douglas Pinheiro in this volume, dedicated to melancholy as a method to understand modernity, has long revealed the error of considering "our intelligence as an autonomous force", independent from "emotional life" and affective interests. Freud (1976) 134-135.

44 It is useful to consider here the findings of Croce (2017) 33-37, on reducing history under the general concept of art. 
Grossi, Paolo (2011), Ordinamento, in: Paolo Grossi - Maestri del diritto, edited by Guido Alpa, Roma-Bari, Laterza, 2011

Heidegger, Martin (1976), Essere e Tempo (1927), Italian translation by Chiodi, 14th ed., Milano, Longanesi \& C.

Husserl, Edmund (2014), Il destino della filosofia (1976), Italian translation by Nicola Zippel, Roma, Castelvecchi

Irti, Natalino (1990), La cultura del diritto civile, in: La cultura del diritto civile, Torino, UTET

Irti, Natalino (2011), La filosofia di una generazione, in: Diritto senza verità, Roma-Bari, Laterza

Kant, Immanuel (2009), La metafisica dei costumi (1797), translated and edited by G. Vidari, Roma-Bari, Laterza

Koselleck, Reinhart (2010), Repetitive structures in language and history, in: Tilmans, Karin, Frank Vanvreee, Jay Winter (eds.), Performing the past: memory, history and identity in modern Europe, Amsterdam, Amsterdam University Press

Mengoni, Luigi (2011), Metodo e teoria giuridica, edited by Carlo Castronovo, Carlo, Antonio Albanese, Andrea Nicolussi, Scritti II, Milano, Giuffrè

Mengoni, Luigi (1992), I principi generali del diritto e la scienza giuridica, in: Mengoni (2011)

Mengoni, Luigi (1996), Ermeneutica e dogmatica giuridica, Milano, Giuffrè

Merkl, Adolf (1987), Il duplice volto del diritto (1918), in: Il duplice volto del diritto. Il sistema kelseniano e altri saggi, Italian transation by C. Geraci, with a foreword by M. Patrono, Milano, Giuffrè

Perelman, Chaïm (1966), Trattato dell'argomentazione: La nuova retorica (1958), with Lucie Olbrecthts Tyteca, Italian translation, with a preface by N. Bobbio, Torino, Einaudi

Portale, Giuseppe B. (2016), Dalla "pietra del vituperio" al "bail-in", delivered by at the Accademia dei Lincei on 15 April 2016

Romano, Santi (1962), L'ordinamento giuridico, $2^{\text {nd }}$ edition, Firenze, Sansoni

Teubner, Gunther (2005), La cultura del diritto nell'epoca della globalizzazione. L'emergere delle costituzioni civili, Italian translation by R. Prandini, Roma, Armando Editore

Vattimo, Gianni (2000), Introduzione a Heidegger (1971), Roma-Bari, Laterza 